\title{
Possible Meningioma Comorbidity in Male Sickle Cell Cyproterone Acetate Recipients; Short Article
}

\author{
ALSHAHRANI* \\ Department of Clinical Pharmacy, College of Pharmacy, TU, KSA, Saudi Arabia \\ *Corresponding author: Alshahrani, Associate Professor, Department of Clinical Pharmacy, College of Pharmacy, TU, KSA, \\ Saudi Arabia
}

\section{ARTICLE INFO}

Received: 㓞 July 28, 2021

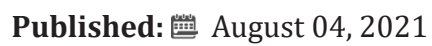

Citation: Alshahrani. Possible Meningioma Comorbidity in Male Sickle Cell Cyproterone Acetate Recipients; Short Article. Biomed J Sci \& Tech Res 37(5)-2021. BJSTR. MS.ID.006056.

\begin{abstract}
Priapism refers to prolonged penile erection that continues for long, yet not associated with sexual arousal or desire. Priapism is often long and painful. It is an uncommon condition, which mostly occurs in male sickle cell anemic patients. Prompt treatment is advisable for prevention of tissue damage that could culminate in erectile dysfunction. There are two types, ischemic, and non-ischemic priapism. The former is also called low flow priapism, where blood does not leave the penis, a form that is common in sickle cell anemic males. The article proposes administration of cyproterone acetate prescription is a valuable preventative medication strategy for limiting priapism and its recurrence. While cyproterone acetate may be a great therapy against priapism, it has massive inherent risks that could counter its usefulness.
\end{abstract}

Keywords: Meningioma; Cyproterone Acetate; Priapism; Grade; Ischemic; Non-Ischemic

\section{Introduction}

Despite the proven usefulness of cyproterone acetate in therapy for priapism, credible concerns arise over its effects on patients as scientific literature correlates it to development of meningioma. Meningioma is a tumor of the primary central nervous system (CNS). This implies that cyproterone acetate is likened to causing meningioma, which begins either in the spinal cord or the brain. Meningiomas are the commonest type of primary brain tumor. This means that administration of cyproterone acetate in this therapy predisposes sickle cell patients to the ordinary meningioma or high grade meningiomas.

\section{Discussion}

Champeaux Depond [1] conducted a clinical research conducted on women in the French Système National des Données de Santé (SNDS) considered cases of meningioma surgeries performed between 2007 and 2017. Out of the patients sampled in this research, 1,1011 female patients representing 3.8\% who were frequent users of cyproterone acetate. The median age at the prescription of cyproterone acetate was 42 years. The median period between the start time for the cyproterone acetate prescription and diagnosis with meningioma was 5.5 years. For patients that used cyproterone acetate treatment, the median age for meningioma surgery was significantly lower, just 47 years in comparison to the population that was not on cyproterone acetate, whose median age for meningioma surgery was 61 years. For the patients in the first group, the median dose of cyproterone acetate was $40 \mathrm{~g}$. From this study, there was clearly a strong case correlating administration of cyproterone acetate and the duration of meningioma development or diagnosis. "Middle skull base was the most common (39\%) location with an anterior skull base insertion being also far more common compared to the usual population with $21.9 \%$ of the tumor" [1]. The research reported that the skull base predominance of meningioma associated with cyproterone acetate is highly notable according to this research. The research concluded that increased cyproterone acetate dose heightened the chances of patients developing multiple meningioma locations and surgeries.

\section{Conclusion}

The National Cancer Institute (2021) [2] says that meningiomas are often most common in females. However, the point of interest here are males with sickle cell, and here is an interesting point from 
the National Cancer Institute. Women are the common meningioma patients but, men are the greatest sufferers of grades II and III meningioma. This should raise quite some concern and greater research into possible meningioma comorbidity in male sickle cell cyproterone acetate recipients. The NIC estimates the relative survival rate for anaplastic and atypical meningioma at $63.8 \%$. However, several factors may potentially affect the prognosis of meningioma. Some are tumor type, grade, cancer traits, health and age of the person at the time of diagnosis, and the response to treatment. Knowing the correlation between cyproterone acetate administration and meningioma, it would be of greater interest to research further on possible effects on the male sickle cell patients to have an understanding of the possibility of meningioma being a comorbidity, and to understand the prognosis of these male sickle cell patients in the event administration of Cyproterone acetate for treatment of recurrent ischemic priapism turns our to accelerate development of meningioma in these patients.

ISSN: 2574-1241

DOI: 10.26717/BJSTR.2021.37.006056

ALSHAHRANI. Biomed J Sci \& Tech Res

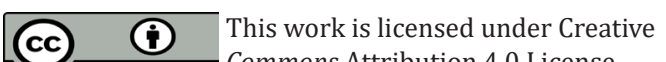

Submission Link: https://biomedres.us/submit-manuscript.php

\section{Funding}

None.

\section{Conflict of Interest}

The authors declare no conflict of interest, financial or otherwise.

\section{Acknowledgement}

The author thanks the college of pharmacy, Taif University for the scientific support.

\section{References}

1. Champeaux Depond C, Weller J, Froelich S, Sartor A (2021) Cyproterone acetate and meningioma: a nationwide-wide population-based study. Journal of Neuro-Oncology 151(2): 331-338.

2. (2021) National Cancer Institute. Meningioma diagnosis and treatment.

$\begin{array}{ll}\text { BIOMEDICAL } & \text { Assets of Publishing with us } \\ \text { RESEARCHES } & \text { - Global archiving of articles } \\ \text { - Immediate, unrestricted online access }\end{array}$

